\title{
PRAWNA OCENA MOŻLIWOŚCI DOKONANIA 6 ZAPŁODNIEŃ OOCYTÓW, POZYSKANYCH W WYNIKU KILKU STYMULACJI
}

\section{LEGAL ASSESSMENT OF THE POSSIBILITIES OF 6 INSEMINATIONS OF OOCYTES OBTAINED FROM SEVERAL STIMULATIONS}

\author{
Anna Wilińska-Zelek \\ WKBWierciński, Kwieciński, Baehr Spółka komandytowa
}

DOI: https://doi.org/10.20883/ppnoz.2019.74

\begin{abstract}
STRESZCZENIE
Wstęp. Przedmiotem rozważań jest prawna dopuszczalność wdrożenia leczenia IVF zmierzającego do kumulacji oocytów w wyniku kilku kontrolowanych hiperstymulacji.

Cel pracy. Celem pracy było przedstawienie aktualnego stanu prawnego i ocena możliwości wdrożenia leczenia ograniczającego ilość zapłodnionych komórek do 6. Materiał i metody. Realizację pracy kazuistycznej przeprowadzono w oparciu o analizę prawną uwzględniającą tok procesu legislacyjnego związanego z nowelizacją ustawy o leczeniu niepłodności (metoda celowościowa i funkcjonalna) wraz z wykorzystaniem literatury przedmiotu.

Wyniki. Ochrona życia i godności ludzkiej w regulacjach wspomaganej prokreacji wynika z woli limitowania ilości zapładnianych oocytów - ilość pobieranych oocytów oraz zastosowane metody ich pobierania pozostaje irrelewantny dla ustawodawcy, o ile w sposób szczególnie negatywny nie wpływają na zdrowie pacjentki. Wnioski. Zaproponowana koncepcja leczenia nie jest przeciwwskazana z prawnego punktu widzenia, o ile pozostaje uzasadniona w świetle rzetelnej analizy algorytmu postępowania leczniczego zindywidualizowanego przypadku.
\end{abstract}

Słowa kluczowe: leczenie niepłodności, stymulacje, IVF, zapłodnienia, oocyty.

ABSTRACT

Introduction. The subject of the deliberations is the legitimacy of the IVF treatment implementation which aims to accumulate oocytes as a result of several controlled hyperstimulations.

Aim of the study. The objective of the paper was to present current legal status and assess the possibility of implementing the treatment limiting the number of fertilized cells to 6 .

Material and methods. The case report was drawn up on the basis of the legal analysis taking account of the legislative process connected with the amendment of the Infertility Treatment Act (purposive approach and functional interpretation) as well as on the basis of the source literature.

Results. Protection of life and human dignity in the regulations on assisted procreation results from the need to limit the number of fertilized oocytes the number of collected oocytes and the applied methods of their collection remain irrelevant to the legislator provided that they do not have a particularly negative influence on the patient's health.

Conclusions. The proposed treatment concept is not contraindicated from the legal point of view provided that it is justified in the light of a reliable analysis of the treatment algorithm for an individual case.

Keywords: Infertility treatment, stimulations, IVF, inseminations, oocytes.

\section{Wstęp}

Pacjentka zainteresowana zatosowaniem procedur medycznie wspomaganej prokreacji dokonała oznaczenia stężenia AMH (Anti-Mullerian Hormone) w surowicy krwi, które jest predyktorem w ocenie poziomu rezerwy jajnikowej. Otrzymany przez nią wynik (ok. 0,2) sygnalizuje obawy o zdolności reprodukcyjne (możliwa bardzo słaba odpowiedź pacjentki na ewentualną stymulację hormonalną przejawiające się w braku możliwości pozyskania oocytów, ich zapłodnienia, a także możliwych odchyleń w zakresie morfologii uzyskiwanych zarodków).

Mając na względzie powyższe czynniki, należy rozważyć możliwość podejścia do kilku stymulacji w celu uzyskania maksymalnie do 6 zapłodnień (tj. skumulowania oocytów w ramach kilku kontrolowanych hiperstymulacji i następnie ich zapłodnienie).

Z uwagi na realizację innych planów życiowych pacjentów, zarodki miałyby być transferowane w bliżej nieokreślonej przyszłości. Mając na względzie powyższe, doszło do sformułowania pytań o zgodność takiej praktyki z ustawą z dnia 25 czerwca 2015 r. o leczeniu niepłodności [1], w szczególności art. 9 ust. 2 ustawy.

\section{Cel pracy}

Celem pracy jest przedstawienie aktualnego stanu prawnego, uwzględniającego ustawę [1] i decyzje podejmowane $w$ toku procesu legislacyjnego [2-6], by ocenić możli- 
wość wdrożenia leczenia zakładającego uzyskanie kilku oocytów, które następnie zostałyby zbiorczo zapłodnione (przy założeniu ograniczenia ilości zapłodnionych komórek do 6).

\section{Materiał i metody}

Realizację pracy kazuistycznej przeprowadzono w oparciu o analizę prawną uwzględniającą tok procesu legislacyjnego wraz z wykorzystaniem literatury przedmiotu w celu dokonania kompleksowej wykładni przepisów wywołujących wątpliwości.

\section{Wyniki (rozważania prawne)}

Zgodnie z art. 9 ust. 2 ustawy o leczeniu niepłodności [1]: „W przypadku zapłodnienia pozaustrojowego dopuszcza się zapłodnienie nie więcej niż sześciu żeńskich komórek rozrodczych, chyba że (...)"

Ustawa limituje ilość zapładnianych komórek rozrodczych, nie ograniczając jednak ilości realizowanych cykli. Brak również jakichkolwiek przepisów, wymuszających zastosowanie zarodków, które zostały wcześniej zamrożone, przed uzyskaniem kolejnych zapłodnień oocytów. Z punktu widzenia analizy językowej brak uzasadnienia dla odmowy wdrożenia opisywanego procesu leczenia. Bez wątpienia znaczne trudności wywołuje jednak sformułowanie jednoznacznego stanowiska w sprawie, z uwagi na brak przejawów piśmiennictwa czy orzecznictwa, które odnoszą się wprost do niniejszego problemu.

Konieczne jest w związku z tym przeprowadzenie procesu wykładni, uwzględniającego metodę celowościową i funkcjonalną. Zwrócić należy bowiem uwagę na to, że przepisy prawa powszechnie obowiązującego odwołują się w zakresie procedur wspomaganej medycznie prokreacji do "wyczerpania innych metod leczenia" czy konieczności upływu konkretnego czasu standardowego leczenia - zaistnienie dopiero tych czynników pozwala na stosowanie procedur zapłodnienia pozaustrojowego. Tym samym ustawodawca leczenie IVF traktuje jako rozwiązanie ostateczne, co sugeruje konieczność zachowania szczególnej ostrożności w podejmowaniu decyzji co do algorytmu postępowania leczniczego konkretnych pacjentów.

Dogłębna analiza procesu legislacyjnego pozwala jednak na dostrzeżenie, iż szeroko dyskutowanym problemem w toku prac była kwestia związana z ilością uzyskiwanych zarodków. Podstawowe wyrażane obawy dotyczyły potencjalnej możliwości doprowadzenia do sytuacji, w której dojdzie do skumulowania nadliczbowej ilości zarodków. Zapłodnienie sześciu komórek rozrodczych, przy uwzględnieniu, iż tylko wybrane komórki posiadają potencjał roz- wojowy, w zamyśle projektodawcy oraz osób uczestniczących w pracach nad ustawą, miało zapobiegać powyżej opisanym sytuacjom.

Pomijając dyskusję dotyczącą słuszności ustanowionych granic [7], nie można nie zauważyć, że maksymalna ilość sześciu zapłodnień (a nie pozyskanych oocytów) jest dla ustawodawcy kluczowa. O niniejszym świadczą w szczególności niektóre dokumenty z monitoringu procesu legislacyjnego:

1) Uzasadnienie Rządowego projektu ustawy o leczeniu niepłodności:

"(...) W przypadku zapłodnienia pozaustrojowego wprowadzono regulacje mające na celu ograniczenie tworzenia nadliczbowych zarodków poprzez wprowadzenie zasady, zgodnie z którą zapłodnieniu podlega nie więce niż sześć żeńskich komórek rozrodczych (...) Zapładnianie maksymalnie takiej liczby (6) komórek rozrodczych (oocytów), pozwala, zgodnie z aktualną wiedzą i praktyką medyczną, uzyskać taką liczbę zarodków, która pozwala na skuteczne przeprowadzenie procedury zapłodnienia pozaustrojowego, przy jednoczesnym minimalizowaniu wpływu na zdrowie kobiety".

2) Fragmenty transkrypcji posiedzenia Komisji Zdrowia nr 202 z dnia 26 maja 2015 r. [4]

„(...) Poseł Grzegorz Sztolcman (PO):

Podsumowując, w ocenie członków podkomisji, projekt stanowi wyraz rozsądnego kompromisu pomiędzy potrzebą uznania praw osób dotkniętych niepłodnością, w szczególności prawa do ochrony zdrowia i korzystania z osiągnięć najnowszej wiedzy i techniki medycznej, ochroną prawa do założenia rodziny oraz prawa do samostanowienia w dziedzinie reprodukcji a potrzebą ochrony zarodków, a także uwzględnienia dobra mającego się narodzić dziecka (...)".

3) Fragmenty transkrypcji posiedzenia Komisji Zdrowia nr 203 z dnia 9 czerwca 2015 r. [5]

„Podsekretarz stanu w MZ Igor Radziewicz-Winnicki:

(...) Po pierwsze - przypominam - nie wolno zapłodnić więcej niż sześć oocytów. Po drugie, istnieje limit czasu przechowywania zarodków. Czyli, mamy przynajmniej dwa bardzo skuteczne mechanizmy, które powodują, że nie istnieje zjawisko nadliczbowych zarodków, i nie będzie istnieć w przyszłości, tym bardziej, że raczej popyt jest większy na zarodki i ludzie już oczekują, bo zjawisko niepłodności nasila się, co jest związane z czynnikami demograficznymi.

Innymi słowy, właśnie wychodząc naprzeciw tym potrzebom, projekt rządowy wprowadził zasadę skutecznej ochrony zarodków i przeciwdziałania powstawaniu nadliczbowych zarodków. (...)

Przewodniczący poseł Czesław Hoc (Pis):

(...) 
Jeśli zakładacie w tej rządowej ustawie, że można tworzyć maksymalnie sześć zarodków w jednym cyklu terapeutycznym a potem mówicie, że są trzy wyjątki (...) Czyli, innymi słowy, w praktyce możecie tworzyć dowolną liczbę zarodków.

Bądźmy racjonalni - wiadomo, o co chodzi: tworzycie dowolną liczbę zarodków, oczywiście, w miarę możliwości pozyskania komórek jajowych, bo nie uzyskacie od kobiety więcej niż dwanaście czy jedenaście w straszliwej hormonalnej hiperstymulacji. (...)

Czyli, krótko mówiąc, nie sześć zarodków, tylko praktycznie dowolna liczba, bo te trzy wyjątki stwarzają taką możliwość i znoszą tę granicę do sześciu zarodków."

4) Fragmenty transkrypcji posiedzenia Komisji Zdrowia nr 203 z dnia 11 czerwca 2015 r. [6]

„Podsekretarz stanu w MZ Igor Radziewicz-Winnicki:

(...) przy zapładnianiu sześciu komórek jajowych uzyskuje się 3,31 zarodków, które następnie można wykorzystać do kolejnych transferów a skuteczność metody jest na poziomie 31\% w skali całego kraju. Czyli, tak naprawdę, po zapłodnieniu sześciu oocytów dochodzi do urodzenia jednego dziecka - tak można powiedzieć w dużym uproszczeniu. (...) Rządowy projekt mówi o zapładnianiu oocytów. Nie każde zapłodnienie oocytu skutkuje utworzeniem zarodka. Dlatego ten błąd formalny trudno będzie w praktyce egzekwować (...)".

Najbardziej istotna dla analizy pozostaje jednak wypowiedź J. Gowina [3, ok. 10 min. 20 sek.]:

„(...) Nie ma tutaj chyba żadnych kontrowersji ani moralnych ani naukowych ani prawnych dotyczących możliwości pobierania w zasadzie dowolnie dużej liczby komórek jajowych. Kontrowersje dotyczą tworzenia tzw. zarodków nadliczbowych i statystyki, które przywołał poseł Hoc dotyczą proporcji ilości wytworzonych zarodków, nie komórek jajowych do udanych przypadków zagnieżdżenia się (...)".

Tym samym, skoro ustawodawca zdecydował się na ochronę życia i godności ludzkiej w regulacjach wspomaganej prokreacji wyłącznie poprzez limitowanie ilości zapładnianych oocytów, ilość pobieranych oocytów oraz zastosowane metody ich pobierania pozostaje irrelewantny, o ile w sposób szczególnie negatywny nie wpływają na zdrowie pacjentki.

\section{Wnioski}

Analiza źródeł prawa powszechnie obowiązującego, uwzględniająca cały proces legislacyjny i wyrażane w jego toku poglądy, pozwala stwierdzić, iż proponowana koncepcja leczenia może zostać zaakceptowana, o ile pozwala na to stan aktualnej wiedzy medycznej.
Mając na względzie powyższe, niezbędna jest rzetelna analiza algorytmu postępowania leczniczego, w szczególności uwzględniająca:

1) różnicę w częstości uzyskiwanych ciąż w zależności od wieku pacjentek, a tym samym rozważenie możliwości wdrożenia procesu leczniczego w jak najszybszym możliwym terminie, co potencjalnie mogłoby wyeliminować ryzyko konieczności kumulowania ilości pozyskiwanych zarodków;

2) konieczność minimalizowania wpływu na zdrowie pacjentki;

3) potencjalną szkodliwość zastosowania wysokich dawek farmakologicznych i możliwych powikłań z tym związanych;

4) potencjalną szkodliwość zastosowania kilku cykli leczniczych i możliwych powikłań (w szczególności wzrostu poziomu przeciwciał przeciw antygenom jajnika anti-ovarian antibodies, AOA).

\section{Oświadczenia}

Oświadczenie dotyczące konfliktu interesów

Autorzy deklarują brak konfliktu interesów.

\section{Źródła finansowania}

Autorzy deklarują brak źródeł finansowania.

\section{Piśmiennictwo}

1. Ustawa z dnia 25 czerwca 2015 r. o leczeniu niepłodności (Dz. U. z 2017 r., poz. 865)

2. Rządowy projekt ustawy o leczeniu niepłodności z 13 marca 2015 r. (druk nr 3245) - w tym projekt ustawy, uzasadnienie, druki z posiedzeń komisji i podkomisji, pisma przedkładane w toku opiniowania, konsultacji, uzgodnień.

3. Posiedzenie z 13 maja 2015 r. (materiał audiowizualny, brak transkrypcji) - http://www.sejm.gov.pl/Sejm7.nsf/ transmisje_arch.xsp?unid=321DEA5F1BD95FA5C1257E3F002867BC; stan na dzień: 29 października $2018 \mathrm{r}$.

4. Fragmenty transkrypcji posiedzenia Komisji Zdrowia nr 202 z dnia 26 maja 2015 r., http://orka.sejm.gov.pl/Zapisy7.nsf/ wgskrnr/ZDR-202, stan na dzień: 29 października 2018 r.

5. Fragmenty transkrypcji posiedzenia Komisji Zdrowia nr 203 z dnia 9 czerwca 2015 r., http://orka.sejm.gov.pl/Zapisy7.nsf/ wgskrnr/ZDR-203, stan na dzień: 29 października 2018 r.

6. Fragmenty transkrypcji posiedzenia Komisji Zdrowia nr 203 z dnia 11 czerwca 2015 r., http://orka.sejm.gov.pl/Zapisy7.nsf/ wgskrnr/ZDR-208; stan na dzień: 29 października 2018 r.

7. Haberko J. Ustawa o leczeniu niepłodności. Komentarz, Wolters Kluwer, Warszawa $2016 \mathrm{r}$.

Zaakceptowano do edycji: 15.12.2019 Zaakceptowano do publikacji: 15.02.2020

Adres do korespondencji:

Anna Wilińska-Zelek

ul. Spokojna 32

62-081 Baranowo

e-mail: annawilinska@gmail.com 